\title{
The city of Osaka in the medieval period: Religion and the transportation of goods in the Uemachi Plateau
}

\section{Hiroshi Niki}

\begin{tabular}{|c|l|}
\hline Citation & City, Culture and Society, 3(1): 15-19 \\
\hline Issue Date & $2012-3$ \\
\hline Type & Journal Article \\
\hline Textversion & author \\
\hline \multirow{5}{*}{ Rights } & $\begin{array}{l}\text { This is the pre-peer reviewed version of the following article: NIKI, H. (2012). The } \\
\text { city of Osaka in the medieval period : Religion and the transportation of goods in the } \\
\text { Uemachi Plateau. City, Culture and Society. 3, 15-19. } \\
\text { CC-BY-NC-ND 4.0 License. http://creativecommons.org/licenses/by-nc-nd/4.0/. } \\
\text { The article has been published in final form at } \\
\text { https://doi.org/10.1016/j.ccs.2012.06.012. } \\
\text { This is not the published version. Please cite only the published version. } \\
\text { この論文は出版社版でありません。引用は出版社版をご利用ください。 }\end{array}$ \\
\hline DOI & \begin{tabular}{l} 
10.1016/j.ccs.2012.06.012 \\
\hline
\end{tabular}
\end{tabular}

\author{
Self-Archiving by Author(s) \\ Placed on: Osaka City University Repository
}

NIKI, H. (2012). The city of Osaka in the medieval period: Religion and the transportation of goods in the Uemachi Plateau. City, Culture and Society. 3, 15-19. https://doi.org/10.1016/j.ccs.2012.06.012 
The Osaka region in the ancient and medieval times had the capitals of Nara and Kyoto to the east and was located so as the Inland Sea touched it on the west. It was located at an important point connecting the capitals, the various regions of western Japan, the Korean Peninsula, and the continent of China.

The Uemachi Plateau, where the Osaka Castle would be located in the Edo era, stood more than 15 meters higher than the surrounding lowlands, and as a result, the capital called Naniwa no miya and Naniwa-kyo were constructed here in ancient times.

However, after the capital was moved to the Yamashiro Province (Nagaoka-kyo / Heian-kyo), there were no longer any important centers of politics in the Uemachi Plateau area.

\section{Shitenno-ji's Monzen-machi (Gate Town)}

In exchange, Shitenno-ji (temple) and its monzen-machi (gate town, or town developed in front of temple or shrine gates came to be the center of this region.

Shitenno-ji was located approximately four kilometers from the northern edge of the Uemachi Plateau and was a temple constructed on the grounds of the plateau. There was a legend that it had been built by Shoutoku Taishi by the early $7^{\text {th }}$ Century, and in ancient times, it was a temple for the spiritual protection of the nation. However, in medieval times, the character of the temple would come to change drastically. What triggered this change was the spread of Jodo-shiso (Pure Land Buddhism).

In Japan, Jodo-shiso spread as a form of Buddhist thought in the late ancient era, and it came to be believed that Gokuraku-jodo (the Land of Pure Bliss) lay to the west. And passing into gokuraku (the land of pure bliss) after dying in this life came to be held as the purpose of this faith. In Jodo-shiso, it was believed that if you prayed towards the setting sun in the west during the ohigan period (the vernal equinox and autumnal equinox), you could feel the sensation of passing into gokuraku. This was called “Nissou-kan.”

Because Shitenno-ji was situated atop a plateau, there was a wide vista towards the Inland Sea of Japan to the west. As a result, it was one of the best sites for "Nissou-kan," and people were able to imagine the scene in which the Amitabha Buddha would come from gokuraku to carry them off. The West Gate of Shitenno-ji came to be regarded as the East Gate (eastern entrance) of Gokuraku-jodo, and many nobles and commoners made pilgrimages to Shitenno-ji.

According to excavational surveys, ruins that show traces of buildings and human life after the $13^{\text {th }}$ Century have been found on the western side of Shitenno-ji. Many splendid buildings are pictured on the western side of Shitenno-ji’s West Gate in “Ippen Shonin Eden (Illustrated Biography of the Priest Ippen),” depicting scenery from the $13^{\text {th }}$ Century. These are presumed to have been the homes of Shitteno-ji’s influential monks. There were probably many homes for monks and laymen serving Shitenno-ji apart from this as well. The bustle of the market to the south of the West Gate has also been depicted in the same "Ippen Shonin Eden.”

The monzen (literally, "in front of the gate") to the west of Shitenno-ji developed into a town, most likely due to the influence of this faith in the West Gate.

The “Ippen Shonin Eden" also shows many beggars residing outside the southern mud walls of Shitenno-ji. Historical sources from the $13^{\text {th }}$ Century also note that a large number of “sick" (patients of Hansen's disease, or leprosy) lived at the West Gate. In 1275, the monk Eison, from the Risshu sect of Buddhism conducted relief measures for the "Hinin (outcastes comprising the lowest rank of the caste system)” at Shitenno-ji.

They were most likely gathered there in hopes of alms from the many people who made pilgrimages to Shintenno-ji. At this time, Shitenno-ji had become the center of faith in Shoutoku Taishi, and many citizens from throughout the nation were 
coming to make pilgrimages. By giving alms to the "sick" and the "hinin," these religious followers were attempting to heighten the religious value of their sect.

Relief work centering on the West Gate of Shitenno-ji continued even afterwards. Stories (in sekkyou <sermons>, etc.) such as that of Shuntokumaru (Shintokumaru) who fell ill, then blind, became a beggar, and wandered into Shitenno-ji where he was revived by alms given him, begun to be widely narrated by the populace after the $15^{\text {th }}$ Century.

There is a historical source entitled “Nanasen-ken no zaisho (The Residences of Seven Thousand Households)” (from around 1499) about the Shitenno-ji monzen-machi (gate town), showing that it was an extremely developed town. Not only did residents from the surrounding agricultural village gather here for commerce, but articles that had been discharged in the ports of Kizu and Watanabe no tsu (to be mentioned later) were also traded here, and it was likely to have been a large-scale market.

The road heading west from the West Gate of Shitenno-ji climbed down the plateau, passed in front of Imamiya-jinja (shrine) and reached the port of Kizu. In Imamiya, there was a community of people called kugonin. These kugonin belonged to the Gion-sha (shrine) in Kyoto, and in return for supplying seafood to the Gion-sha, were given the special privilege to move freely throughout the nation. They thus became merchants, conducting commercial activities dealing in various products. A monzen-machi (gate town) was formed at Imamiya-jinja (shrine), and kugonin as well as other merchants came to reside there.

The port of Kizu was a fishing port as well as a commercial port. A great amount of clam shells have been found in the remains of Shitenno-ji's monzen district (district in front of the temple's gate) from the Kamakura era. Because it was much too great a number to have been consumed only in the Shitenno-ji district, it is speculated that some sort of processing was done here, after which they were shipped towards the Kyoto and Nara areas. These clams were likely collected from Osaka Bay and discharged at the port of Kizu.

Kizu was also the outer port for Shitenno-ji and Imamiya-jinja. Articles of trade as well as the produce from surrounding agricultural villages were brought in to the "Shitenno-ji Hama-ichi (Shore market affiliated to Shitenno-ji)," and it is known to have been a center for distribution. It is speculated that this "Hama-ichi” was held in Kizu. In 1361, along with an earthquake, a large-scale tsunami hit this region, and a vast amount of damage has been recorded from it.

\section{Watanabe no tsu}

In the medieval period, a port town named Watanabe had developed to the west of the northern end of the Uemachi Plateau.

At the time, the Yodogawa (river) from the north and Yamatogawa (river) from the east flowed into this region, and it was a few kilometers from the Watanabe no tsu area to the sea of Osaka Bay. In ancient times, the Naniwa tsu, the outer port of Naniwa no miya and Naniwa-kyo, is supposed to have been in this location.

From Watanabe no tsu, if you went upstream along the Yodogawa (river) running along the border of Settsu and Kawachi Provinces, you would reach the Yamashiro Province, and if you went ashore at Yodo or Fushimi, you would soon reach Kyoto. However, because ships that had sailed through the Inland Sea could not simply go upstream on the Yodogawa (river) as was, it had to transfer its cargo to a riverboat at some port town. Watanabe no tsu is believed to have continued to develop as a junction port along such a key route, even after the dissolution of Naniwa-kyo.

However, after the $8^{\text {th }}$ Century, when the water depth at the estuary of Yodogawa (river) became shallow due to sediment deposit, upstream travel became difficult and ships from Osaka Bay were no longer able to land in Watanabe no tsu. The key route from the Inland Sea to Kyoto was changed into one in which the middle reaches of Yodogawa (river) were approached through Amagasaki and Kanzakigawa (river).

The main route for the transportation of goods thus strayed away from Watanabe no tsu, but many travelers still continued to use Watanabe no tsu. Travelers who had come downstream on the Yodogawa (river) from Kyoto disembarked at Watanabe no tsu and journeyed along the land route. They then traveled south from Watanabe no tsu to Shitenno-ji, then to 
Sumiyoshi and Sakai. From Sakai, they were able to embark a ship sailing along the Inland Sea, or, it was also possible to voyage on towards the Izumi and Kii Provinces along the land route. Of course, travelers from Western Japan or foreign countries traveled along an opposite route.

Watanabe no tsu was thus a node that connected to the water route along Yodogawa (river) leading to Kyoto and to the land route connecting the western side of the Uemachi Plateau from north to south, and developed as a traffic terminal through the medieval period.

Watanabe no tsu was a port town on the southern banks of the Yodogawa (river), but the Watanabe Tenman-gu (currently Osaka Tenman-gu Shrine, Tenma Ten-jinja) was located on the opposite bank. The shrine was founded before the $9^{\text {th }}$ Century, and was the local Shinto deity for the region (the Nakajima region on the northern bank of the Yodogawa) at the time. As its monzen-machi (gate town) is believed to have also been a port town on the northern bank of the Yodogawa in the Middle Ages, it can be said that Watanabe no tsu developed along both the southern and northern banks of the Yodogawa.

The road running in front of the gates of the Tenman-gu (shrine) from Watanabe no tsu passed through the east side of the Senri Hills from Suita, and merged with the Saigoku Kaido (road) near Ibaraki. As the Saigoku Kaido was a road that connected Hyogo tsu (Kobe City) with Kyoto, it can be said that Watanabe no tsu was connected to Kyoto by this route as well.

In the late $13^{\text {th }}$ Century, Shunjobo-Chogen took note of this advantageous positioning of Watanabe no tsu. Chogen was commissioned with the rebuilding of the Todai-ji (temple) in Nara, and was looking to develop a route for transporting the lumber for this reconstruction from the Suo Province (Yamaguchi Prefecture) to Nara. Chogen was attempting not only to set a temporary transportation route, but to control a distribution route that would support the economic activity of Todai-ji (temple) on a longer-term. Chogen established centers at all the important points along this distribution route - Watanabe no tsu was one of these. He constructed a building called Jodo Hall in Watanabe no tsu, and it is believed that he established branches of the Todai-ji surrounding it. In this way, Watanabe no tsu came to be not only an economic center but also a religious center and embodiment of Jodo-shiso (Pure Land Buddhism).

The exact location of the Jodo Hall remains unknown, but it is speculated to have been built on the western slope of the Uemachi Plateau, to the eastern side of Watanabe no tsu. Not only could Watanabe no tsu be taken in at a glance from the Jodo Hall, but there was also likely a vista opening out from the Osaka Bay, stretching to the west, to the Inland Sea. Able to look out on to the direction of Hyogo tsu (Kobe City), another center of Todai-ji, it was also able to take in the panorama from which you could sense the Gokuraku-jodo (the Land of Pure Bliss) to the west, as in the Shitenno-ji.

The Jodo Hall continued in to the $16^{\text {th }}$ Century. The existence of many temples in Watanabe, apart from the Jodo Hall, throughout the medieval times can be observed through historical records. Also according to excavational surveys, with activities such as the influx of Chinese ceramics and porcelain, Watanabe no tsu maintained its position as an economic terminal throughout the medieval period.

In the late medieval period, Watanabe Sanjo (a manor, or estate of the second class, wherein a great part of its residents are believed to have been those who were subject to discrimination) would be established. It is believed that the people of the Sanjo took charge of land and water traffic with Watanabe no tsu as their base.

\section{Kumano Kaido}

It was the Kumano Kaido, with its base in Watanabe no tsu, that passed through Shitenno-ji and Sumiyoshi and lead towards the Sakai direction.

Faith in Kumano Sanzan (the three major shrines, Kumano Hongu Taisha, Kumano Hayatama Taisha and Kumano Nachi Taisha) located in the south of the Kii Province began to be popular with the Imperial Family in Kyoto during the $11^{\text {th }}$ Century, and the pilgrimages of groups that reached a few thousand were undertaken close to 100 times. The Kumano Kaido was thus maintenanced as a passage for these groups of pilgrims. After the $13^{\text {th }}$ Century, the general populace began to make 
pilgrimages to Kumano as well, the number of those traveling along the road increased, and it continued to develop. The Kumano Kaido was the most used and famous pilgrimage route in Japan during the medieval times.

Pilgrims to Kumano who had traveled by ship from the Kyoto direction disembarked at Watanabe no tsu and moved on to the Kumano Kaido. Places for worship from afar called Ouji were set at various places along the Kumano Kaido, and pilgrims continued along their route, stopping to pray at each Ouji. At Watanabe no tsu was the first Ouji, Kubotsu Ouji. The first place that Kumano pilgrims stayed at was the monzen (front of the temple gates) of Shitenno-ji.

Apart from this, in the early medieval times, the Emperor and his family as well as the nobles made pilgrimages to Mt. Kouyasan in the Kii Province (Wakayama Prefecture) as well. Many of these pilgrims, after proceeding to the capital, also traveled the land route from Watanabe no tsu or the water route from Sumiyoshi, to head to Mt. Kouyasan.

Kumano Kaido, maintenanced for religious reasons, eventually developed into a key traffic route running through the region. It can be said that the flow of those making pilgrimages to religious institutions not only contributed to road maintenance and upkeep but to the invigoration of the economy of Uemachi Plateau's northern district and brought about urban development.

\section{Osaka (Ishiyama) Hongan-ji’s Jinnaichou (Temple Compound Town)}

After the dissolution of Naniwa no miya / Naniwa-kyo, while Watanabe no tsu, lying below the Uemachi Plateau to the west, flourished, there were no villages on the plateau with large buildings or many residents. It was Rennyo, who revived the Jodo Shinshu sect, who noted the prominent characteristics of this location. At the end of the $15^{\text {th }}$ Century, Rennyo constructed a retreat in this location. It was in the document where Rennyo first noted this that the name of this region, "Osaka," first appeared.

Why was this place called “Osaka,” in other words, “ookina saka (a large hill)”? There was most likely a sloped road climbing up from the largest city in this region, Watanabe no tsu, to the Uemachi Plateau. This road may have passed through the plateau to the east and connected to the Kawachi Province. It is speculated that this sloped road was called "Osaka,” and the surrounding region was named so in connection to it.

In the $16^{\text {th }}$ Century, Osaka-gobo (one of the limited main temples of Jodo Shinshu, a temple under its direct control) would come to be the gathering point of Jodo Shinshu sect followers in the Settsu and Kawachi Provinces. Residences of monks and followers came to be built around the Gobo and developed into a city. A characteristic of cities belonging to a Jodo Shinshu sect temple was that the city in which trade or manufacture took place would lie, not at the monzen (in front of the gates) of the temple, would be formed within the temple grounds. That is why they were called "jinnaichou (temple compound towns, or towns developed within the temple precincts).” As a result, protection measures equal to those of the temple applied to the town as well, characterizing the city based on this quality.

After the 1530's, Osaka-gobo, situated at the center of Osaka’s temple compound town, became Hongan-ji (temple), the national head of the Jodo Shinshu sect. At the heart of Hongan-ji, apart from religious facilities such as the Amida Hall, were the residential quarters for the suzerain as well as monks' housing, and a town spread around it. There were six local communities in the town, and it realized a certain amount of autonomy. The entire population of Osaka is presumed to have been from a few thousand to ten thousand.

Apart from those serving the Hongan-ji (temple), many craftsmen, merchants, and farmers resided in the town as well. There were also more than a few financiers, inns, and samurai warriors. There is also known to have been professional castle builders there as well. Due to the pilgrimages made to Hongan-ji (temple) by all the followers of the Jodo Shinshu sect across the nation, an enormous flow of finances and traffic occurred within and outside the jinnaichou (temple compound town).

It is said that the Jodo Shinshu sect developed from the Risshu sect and faith in Shoutoku Taishi in the early medieval

times. Many people who were discriminated against in the $16^{\text {th }}$ Century are said to have converted to the Shinshu sect, and such people, including craftsmen and entertainers, lived in Osaka. 
The jinnaichou (temple compound town) was encircled by a huge mud wall, with wooden towers constructed at important positions to heighten military protection. It had its own port on the Yodogawa (river); and there are records of Chinese ships having entered this port.

Centering on the Osaka Hongan-ji (temple), about 20 jinnaicho (temple compound towns) were established in the Osaka Plain in the middle of the $16^{\text {th }}$ Century. These jinnaichou connected to Osaka through religious faith and distribution, were equipped with a mutual aid system in case of war.

One of the characteristics of jinnaichou (temple compound towns) was that, in contrast to many cities in Japan during medieval times, they had a system of mutual cooperation between the cities. This was not an equal urban alliance, displaying a hierarchical structure with Osaka at its top. Many of the jinnaichou that developed in the $16^{\text {th }}$ Century continued to be the nucleic city in each of their regions even after the $17^{\text {th }}$ Century, and are currently the satellite cities of Osaka.

Hongan-ji and its temple compound town on the Uemachi Plateau were called by the name of “Osaka” in the $16^{\text {th }}$ Century and the generally well-known name of “Ishiyama” was given by later generations.

\section{The City and Religion / Distribution}

As we have explored above, the cities of Osaka in the medieval period, and especially those around the Uemachi Plateau, were established and developed in connection to religious faith, the temple, and Buddhist influence.

In the medieval period of Japan, religious influence held power not only over religious faith but also on various aspects of society including the economy, military, and culture. This was a characteristic shared not only by "Old Buddhism” such as the Tendai sect and Shingon sect, but also by "New Buddhism” including the Zen sect, Hokke (Nichiren) sect, and the Jodo Shinshu sect.

As a result, large-scale religious institutions called in large numbers of followers, places for the creation of goods and commerce were born, and a city ensued. Or, perhaps on the contrary, it was religious influence that advanced onto the cities that gathered people.

As mentioned at the beginning, because the Osaka region in medieval times was located at the juncture of the traffic route connecting the capital of Kyoto, Western Japan, the Korean Peninsula, and the continent of China, it became a hub of economic activity and distribution as well as cultural interaction. Because of this, various cities were established and religious influence penetrated throughout.

The fact that the Uemachi Plateau had been formed with the topographical conditions to provide a full view of the Osaka Bay, to the west of the Inland Sea, was an important factor to the Osaka region becoming a religiously sacred place. In the medieval period of Japan, there was an especially strong desire for passing into gokuraku (pure bliss); and thus, this was likely why the religious faith at the West Gate of Shitenno-ji, Chogen's Jodo Hall, and the Amida Hall at Hongan-ji were born at this place where you could experience “Nissoukan,” or the sense of passing into gokuraku.

Just as the Kumano Kaido, passing through such sacred grounds, was a pilgrimage route, the cities of Osaka in medieval times and the distribution system in these cities were characteristic for its extremely strong religious color. At the same time, the fact that such mid to small scale urban networks functioned across the differences of the various religious sects, can be noted as a characteristic of Osaka in the medieval period.

Such holy grounds and cities of religion also had the power to draw in the poor, such as the "sick" or the "hinmin" requiring relief. The lower class, belonging to such urban occupations as transportation, cleaning, funeral services, and entertainment, or those who were sick or physically disabled gathered in the cities of Osaka and its peripheries in medieval times, seeking their daily food and hoping for the happiness of future generations. Shitenno-ji was an especially large national center, and many religious followers are known to have been active in the area.

The unified authority, Oda Nobunaga, who came forward to claim de facto control over the Osaka region in the late 
1560's valued the usefulness of this area based on political and economic perspectives, and tried to put the city and its distribution system under the control of the samurai. The samurai clan that dominated the 10 year war against Hongan-ji later built an enormous castle on the grounds of the Hongan-ji, and developed a wide-ranging castle town that encompassed Watanabe no tsu and the monzen machi (gate town) of Shitenno-ji.

At the end of the $16^{\text {th }}$ Century, cities of the Osaka region would come to drastically change from medieval times into the early modern period.

\section{References}

Shinshu Osaka-shi Shi (honbun-hen) (History of Osaka: New Edition $<$ text $>$ ) Vol. 2

Shinshu Osaka-shi Shi Shiryou-hen (History of Osaka: New Edition Historical Records) Vol. 2 and 3

Osaka no Buraku-shi (History of Osaka Buraku) Vol. 1 (Historical Records), Buraku Liberation Publishing House Co., Ltd. 